\title{
PARIWISATA, PERTUMBUHAN EKONOMI DAN KETIMPANGAN DISTRIBUSI PENDAPATAN DI BALI \\ (Hipotesis Kurva Kuznets)
}

Daru Tri Rekso Joko Nuryanto

Kantor Pelayanan Perbendaharaan Negara Denpasar

Alamat Korespondensi: darudevill@gmail.com

\section{INFORMASI ARTIKEL}

Diterima Pertama

11 Agustus 2017

Dinyatakan Diterima

7 Desember 2017

KATA KUNCI:

Pertumbuhan Ekonomi, Pengeluaran Pemerintah Daerah, Pariwisata, Gini Ratio, Kuznets Curve

KLASIFIKASI JEL:

C230, H720, 0410

\section{ABSTRAK}

Many researchers agree that tourism can increase economic growth and household's incomes, but disagreed with their role in distribution. This study seeks to see the relationship between the tourism industry and growth to the inequality of income distribution in Bali. Using regression of panel data from 9 districts /cities in Bali from 2006 to 2015 shows the tourism sector and growth has an effect on increasing inequality of income distribution.

Banyak peneliti yang sepakat bahwa pariwisata dapat meningkatkan pertumbuhan ekonomi dan pendapatan masyarakat, namun berbeda pendapat terhadap perannya dalam mendistribusikan pendapatan di rumah tangga. Penelitian ini berusaha untuk melihat hubungan antara pariwisata dan pertumbuhan ekonomi terhadap ketimpangan distribusi pendapatan di Bali. Berdasarkan hasil regresi data panel dari 9 kabupaten/kota di Bali periode tahun 2006-2015, penelitian ini menemukan bahwa sektor pariwisata dan pertumbuhan ekonomi memiliki pengaruh pada kenaikan tingkat ketimpangan distribusi pendapatan masyarakat. 


\section{PENDAHULUAN}

\subsection{Latar Belakang}

Dalam dasawarsa terakhir ini banyak negara berkembang menaruh perhatian khusus terhadap industri pariwisata. Sektor pariwisata menjadi salah satu sektor ekonomi yang tumbuh paling cepat di dunia melalui pertumbuhan dan tingkat diversifikasi. Selain itu, sektor pariwisata juga tidak begitu terpengaruh oleh gejolak dan pelemahan ekonomi global, berbeda halnya dengan sektor komoditas. United Nations World Trade Organization (UNWTO) menyebutkan bahwa pada tahun 2015 pariwisata menyumbang 10\% dari total GDP seluruh dunia, menawarkan 1/11 kesempatan kerja yang ada, menghasilkan USD1,5 triliun ekspor yang merupakan $7 \%$ dari total seluruh ekspor di dunia dan 30\% dari seluruh ekspor jasa. Pada kasus Indonesia, kontribusi sektor pariwisata terhadap Produk Domestik Bruto (PDB) menempati urutan keempat, berada dibawah minyak dan gas, batubara dan minyak kelapa sawit. ${ }^{1}$

Pariwisata mempunyai konsekuensi adanya pertemuan dua budaya atau lebih yang berbeda, yaitu budaya masyarakat lokal dengan budaya para wisatawan. Budaya-budaya yang berbeda dan saling bersentuhan tersebut dapat membawa pengaruh yang menimbulkan dampak terhadap aspek kehidupan masyarakat di sekitar objek wisata (Yoeti, 2008)². Setidaknya ada empat bidang pokok yang dipengaruhi oleh usaha pengembangan pariwisata, yaitu: ekonomi, sosial, budaya, dan lingkungan hidup. Dampak positif pariwisata dalam bidang ekonomi yaitu kegiatan pariwisata mendatangkan pendapatan devisa negara, terciptanya kesempatan kerja, dan adanya kemungkinan bagi masyarakat di daerah tujuan wisata untuk meningkatkan pendapatan dan standar hidup. Sementara itu, dampak negatif dari pengembangan pariwisata tampak menonjol pada bidang sosial berupa perubahan gaya hidup masyarakat (sikap, tingkah laku, dan perilaku) di daerah tujuan wisata. Kerusakan lingkungan juga tidak lepas dari konsekuensi pengembangan pariwisata.

Provinsi Bali memiliki peran strategis terhadap pariwisata di Indonesia. Sektor pariwisata merupakan sektor andalan dan solusi dari keterbatasan sumber daya alam di Bali. Keterkaitan suatu sektor terhadap berbagai sektor

1 Data dari Kementerian Pariwisata, Rangking Devisa Pariwisata terhadap Komoditas Ekspor Lainnya tahun 2011 s.d 2015.

2 Oka A. Yoeti, "Perencanaan dan Pengembangan Pariwisata", (Jakarta: Pradnya Paramitha, 2008), Hal.144. lain nantinya akan berpengaruh sejauh mana sektor pariwisata mampu meningkatkan produktivitas dari sektor-sektor lainnya. Akal (2010), Lee \& Chang (2008), Mudrikah et al (2014), dan Nizar (2011) secara empiris membuktikan bahwa pariwisata meningkatkan PDB serta pertumbuhan ekonomi suatu negara atau wilayah. Ashley, Roe, \& Goodwin (2001) menyebutkan bahwa pro poor tourism (PPT) berpengaruh sangat signifikan dan positif terhadap keterbukaan kesempatan kerja baru, peningkatan dan pemerataan pendapatan, dan kesejahteraan masyarakat. Namun demikian, jika pertumbuhan yang tinggi juga disertai dengan tingkat kesenjangan yang tinggi, dapat dipastikan bahwa ada beberapa kelompok masyarakat yang termarjinalkan dari kemampuan ekonomi di sekitarnya (Bappeda Provinsi Bali, 2015). ${ }^{3}$

Pertumbuhan ekonomi Provinsi Bali selama 9 tahun terakhir cenderung berfluktuatif dan pada tahun 2015 mencapai 6,04 persen. Pola pertumbuhan ekonomi Bali dengan pertumbuhan ekonomi nasional juga dapat dikatakan serupa. Meskipun sama-sama menunjukkan gejala pelambatan sejak tahun 2011 akan tetapi tingkat pertumbuhan ekonomi Bali masih berada di atas nasional. Kuatnya pertumbuhan ekonomi Bali didorong oleh kontribusi sektor pariwisata yang menjadi tulang punggung perekonomian Provinsi Bali. Peningkatan kunjungan wisatawan ke Bali ditunjang oleh kemajuan di bidang transportasi dan teknologi.

Menurut UNWTO (2016) pelemahan ekonomi dunia tidak terlalu berdampak pada minat kunjungan wisatawan masyarakat dunia. Kunjungan wisatawan dunia di tahun 2015 naik empat persen dibandingkan dengan tahun 2014.

Masalah ketimpangan distribusi pendapatan menjadi persoalan yang rumit dalam pelaksanaan pembangunan ekonomi terutama negara-negara berkembang seperti di Indonesia. Pada golongan penduduk berpendapatan rendah, kondisi ini menyebabkan semakin rendahnya kemampuan daya beli dan semakin rendahnya tingkat kesejahteraan penduduk golongan tersebut. Untuk mengukur tingkat pemerataan pendapatan umumnya digunakan Indeks $\mathrm{Gini}^{4}$ (Gini Ratio) dan kriteria Bank Dunia. Kedua indikator tersebut menghitung berapa persen bagian dari total

3 Badan Perencanaan Pembangunan Daerah Provinsi Bali, "Profil Kemiskinan Provinsi Bali 2014" (Denpasar: Bapeda Bali, 2015), Hal.37.

4 Koefisien Gini merupakan salah satu ukuran yang memenuhi empat kriteria yaitu prinsip anonimitas, independensi skala, independensi populasi dan transfer (Todaro \& Smith, 2009). 
pendapatan penduduk suatu wilayah yang diterima oleh penduduk pada masing-masing golongan pendapatan.

Ketimpangan distribusi pendapatan pada Kabupaten/Kota di Provinsi Bali cenderung mengalami kenaikan dari tahun 2011 sampai dengan tahun 2014 dan menurun di tahun 2015 Dari sisi pemerataan pendapatan, disparitas pendapatan di Provinsi Bali mengalami perbaikan yang tercermin dari penurunan Gini Ratio pada tahun 2015. Gini Ratio Bali pada tahun 2015 tercatat sebesar 0,38, jauh lebih rendah jika dibandingkan dengan Gini Ratio tahun 2014 yang sebesar 0,42 dan nasional sebesar 0,41. Namun demikian, masih tingginya nilai gini ratio Provinsi Bali tersebut mengindikasikan masih adanya ketimpangan pendapatan di Provinsi Bali.

\section{KERANGKA TEORI DAN PENGEM- BANGAN HIPOTESIS}

Hubungan antara pariwisata, pertumbuhan ekonomi dan ketimpangan sudah banyak diperdebatkan oleh para peneliti. Blake et al (2008) meneliti pengaruh pariwisata dalam mengurangi ketimpangan pendapatan di Brasil. Hasil studi tersebut menemukan bahwa pariwisata memberi manfaat pada bagian masyarakat dengan pendapatan terendah dan mengarah ke pemerataan pendapatan melalui perubahan transfer pendapatan, harga dan pemerintah. Namun Blake (2008) pada penelitian yang berbeda menemukan bahwa industri terkait pariwisata secara substansial kurang memberikan pendapatan untuk rumah tangga miskin apabila dibandingkan dengan kegiatan ekspor pada tiga negara di kawasan Afrika Timur (Kenya, Tanzania, dan Uganda).

Pariwisata akan meningkatkan pendapatan rumah tangga, namun pada rumah tangga dengan tingkat pendapatan yang tinggi manfaat yang diperoleh lebih tinggi dibandingkan pada rumah tangga dengan tingkat pendapatan yang rendah. Marcouiller \& Xia (2008) berpendapat bahwa ketimpangan distribusi pendapatan pada pekerja yang sensitif pada sektor pariwisata di Amerika terdapat pada lapangan pekerjaan yang memiliki upah kerja yang tinggi, seperti pada seni pertunjukan dan olahraga. Sebaliknya, pada lapangan kerja dengan upah kerja yang rendah (makanan dan minuman) cenderung memiliki tingkat distribusi pendapatan yang cenderung merata.

Alam dan Paramati (2016) melakukan penelitian di negara-negara berkembang dari tahun 1999-2012. Hasil penelitian menunjukkan bahwa ketimpangan distribusi pendapatan disebabkan karena manfaat pengembangan pariwisata hanya terbatas dinikmati pada kelas atas dalam masyarakat, seperti pemilik penyedia layanan pariwisata, pengusaha, investor dan manajer dari perusahaan pariwisata. Sedangkan Incera et al. (2015) dalam penelitian pada daerah maju di Galicia, Spanyol berpendapat bahwa rumah tangga dengan pendapatan tinggi mempunyai ketergantungan yang lebih pada pariwisata jika dibandingkan dengan rumah tangga dengan pendapatan rendah.

Hasil penelitian Wattanakuljarus dan Coxhead (2008) menyebutkan bahwa peningkatan sektor pariwisata di Thailand menyebabkan kenaikan pendapatan rumah tangga agregat namun justru memperburuk distribusi pendapatan. Pihak yang mendapat manfaat dalam peningkatan sektor pariwisata adalah rumah tangga dengan high income dan bukan dari sektor pertanian. Hal ini disebabkan karena pariwisata di Thailand bukan merupakan sektor padat karya.

Penelitian Lee (2011) menemukan bahwa ketimpangan tinggi serta peningkatan ketimpangan yang lebih cepat terjadi pada daerah di Amerika yang memiliki ketergantungan di sektor jasa pariwisata. Daerah dengan tingkat pendapatan yang tinggi juga mengalami ketimpangan pendapatan yang lebih tinggi.

Beberapa penelitian lain memperoleh hasil yang berbeda yaitu pariwisata berperan dalam penurunan tingkat ketimpangan distribusi pendapatan (Ashley, Roe, \& Goodwin, 2001; Gatti, 2013; C. Lee \& Kang, 1998; Hengyun Li, Jason-Li Chen, Li, \& Goh, 2016). Lee dan Kang (1998) dengan menggunakan Koefisien Gini untuk mengukur ketimpangan dan kurva Lorenz untuk distribusi pendapatan di industri yang berbeda, menemukan bahwa pariwisata menghasilkan distribusi pendapatan yang relatif lebih sama dan lebih baik daripada industri sekunder dan tersier (pertambangan, manufaktur, konstruksi, keuangan, dan pelayanan sosial).

Ashley, Roe, dan Goodwin (2001) melakukan enam studi kasus yang dilakukan di Afrika Selatan, Namibia, Uganda, St Lucia, Ekuador dan Nepal. Hasil penelitian menemukan bahwa peran pro poor tourism (PPT) sangat signifikan dan positif terhadap kesempatan kerja baru, peningkatan dan pemerataan pendapatan dan kesejahteraan masyarakat, pertumbuhan pelaku kegiatan ekonomi mikro, dan berkurangnya jumlah penduduk miskin.

Penelitian Petra Gatti (2013) di Kroasia menunjukkan bahwa ekspansi pariwisata memiliki dampak positif pada kesejahteraan rumah tangga, namun dampaknya lebih kecil dari yang diharapkan untuk mengurangi ketimpangan distribusi pendapatan. Li et al. (2016) menemukan 
bahwa pengembangan pariwisata akan memberikan kontribusi terhadap pengurangan ketimpangan regional di China. Hasil lainnya adalah bahwa wisatawan domestik memberikan akselerasi yang lebih baik pada konvergensi ekonomi regional jika dibandingkan dengan wisatawan internasional. Penelitian lain dilakukan oleh Anwar (2012) yang menemukan bahwa pariwisata di Bangladesh berpengaruh signifikan terhadap peningkatan perekonomian masyarakat miskin. Selain itu, nilai sosial budaya masyarakat lokal dapat dipertahankan dari pengaruh asing dan mampu meningkatkan penghasilan dan kesejahteraan masyarakat.

Pariwisata memegang peranan penting dalam perekonomian Bali. Pariwisata memberikan kontribusi dalam penciptaan lapangan kerja, Peningkatan PDRB serta pertumbuhan sektor informal dan swasta. Melalui efek multiplier yang tinggi, pertumbuhan ekonomi di Bali sangat tergantung pada sektor pariwisata. Namun pertumbuhan ekonomi yang tinggi belum tentu diikuti dengan penurunan angka ketimpangan pendapatan.

Menurut Kuznets $(1955)^{5}$, terdapat korelasi positif antara laju pertumbuhan dengan ketimpangan distribusi pendapatan. Semakin tinggi pertumbuhan ekonomi atau semakin besar pendapatan per kapita, semakin besar pula perbedaan antara kaum miskin dan kaum kaya. Dalam jangka pendek ada korelasi positif antara pertumbuhan pendapatan perkapita dengan kesenjangan pendapatan, namun dalam jangka panjang hubungan keduanya menjadi korelasi yang negatif. Artinya dalam jangka pendek meningkatnya pendapatan akan diikuti dengan meningkatnya kesenjangan pendapatan dan dalam jangka panjang peningkatan pendapatan akan diikuti dengan penurunan kesenjangan pendapatan. Observasi ini dikenal sebagai kurva Kuznets (Kuznets Curve) "U-terbalik" karena adanya pola perubahan longitudinal (time-series) dalam distribusi pendapatan. Koefisien Gini tampak seperti kurva berbentuk "U Terbalik", seiring dengan naiknya pendapatan.

5 Kuznets, Economic Growth and Income Inequality. The American Economic Review, 45(1), (1955) hal 18.
Gambar 1. Kurva "U Terbalik" Kuznets

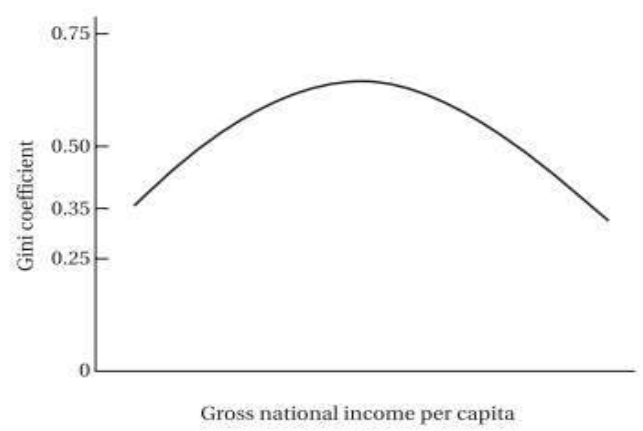

Sumber: Todaro \& Smith (2012)

Kuznets menunjukkan adanya trade off atau pilihan antara pertumbuhan PDRB dengan distribusi pendapatan. Tingkat ketimpangan yang semakin memburuk pada tahapan awal pertumbuhan ekonomi terkait adanya perubahan struktural yaitu pada tahap awal pembangunan ekonomi berkonsentrasi pada sektor industri modern yang kesempatan kerjanya terbatas tetapi memiliki tingkat upah dan produktivitas yang tinggi 6 .

Kaldor (dalam Li \& Zou, 1998) berpendapat bahwa ketimpangan distribusi pendapatan merupakan necessary condition dan insentif yang baik bagi peningkatan pertumbuhan ekonomi. Pendapatan pengusaha maupun perorangan yang tinggi akan menaikan rasio tabungan, tabungan yang tinggi akan meningkatkan investasi dan pertumbuhan ekonomi. Jadi semakin tidak merata pola distribusi pendapatan, semakin tinggi pula laju pertumbuhan ekonomi. Kuznets dan Kaldor menunjukkan adanya "trade off" atau pilihan antara pertumbuhan GDP yang cepat tetapi dengan distribusi pendapatan yang tidak merata, atau pertumbuhan GDP yang lambat tetapi dengan distribusi pendapatan yang lebih merata. Apabila dikaitkan dengan pilihan terhadap berbagai alternatif, ketimpangan merupakan opportunity cost apabila menginginkan pertumbuhan (Krongkaew \& Kakwani, 2003) ${ }^{7}$.

Pemerataan hasil pembangunan dan pertumbuhan ekonomi yang tinggi merupakan

6 Dalam konteks hubungan pariwisata dan ketimpangan distribusi pendapatan, diharapkan adanya hipotesis kurva Kuznets yang menunjukkan bahwa industri pariwisata dapat meningkatkan ketimpangan pendapatan pada tahap awal pembangunannya (Alam \& Paramati, 2016)

7 M. Krongkaew \& N. Kakwani, The growth-equity trade-off in modern economic development: The case of Thailand. Journal of Asian Economics, 14(5), 2003, hlm. 735-73. 
tujuan pembangunan yang ingin dicapai. Tingkat pertumbuhan yang tinggi tanpa disertai pemerataan pembangunan menciptakan perekonomian yang lemah dan eksploitasi terhadap sumber daya manusia. Menurut Bank Dunia (2015), ketimpangan di Indonesia diakibatkan oleh empat hal, yaitu: ketimpangan peluang, ketimpangan konsentrasi kekayaan, dan ketimpangan dalam menghadapi guncangan. Perbaikan layanan umum, penguatan program perlindungan sosial, pelatihan keterampilan bagi tenaga kerja, penyediaan lapangan kerja yang lebih baik, penggunaan pajak dan belanja pemerintah untuk mengurangi ketimpangan serta peningkatan ketaatan pajak merupakan solusi untuk mengatasi ketimpangan.

Peran pemerintah untuk mengatasi ketimpangan sangat penting. Musgrave, (1993) mengidentifikasi 3 (tiga) jenis fungsi dari pemerintah yaitu fungsi alokasi, fungsi distribusi dan fungsi stabilisasi. Fungsi alokasi merupakan peran pemerintah untuk mengusahakan agar upaya pengalokasian sumber-sumber daya ekonomi dapat dimanfaatkan secara optimal. Pengalokasian sumber daya harus dilakukan secara merata, melalui penyediaan barang publik yang tidak dapat disediakan swasta dan tidak dapat diperoleh melalui sistem pasar. Fungsi Distribusi berarti pemerintah bertanggung jawab untuk melakukan distribusi pendapatan dan kesejahteraan dalam masyarakat. Peran ini memiliki keterkaitan dengan pemerataan kesejahteraan masyarakat. Fungsi yang ketiga adalah fungsi stabilisasi. Fungsi ini merupakan peran pemerintah untuk menyelaraskan kebijakankebijakan yang ada dan memiliki keterkaitan erat dalam mengatur variabel ekonomi makro untuk mencapai stabilitas nasional.

Dalam melaksanakan fungsi tersebut, pemerintah menjalankan dua kebijakan ekonomi, moneter dan fiskal. Kebijakan fiskal dan moneter memiliki beberapa tujuan, yaitu: mengatasi masalah-masalah pokok makroekonomi yang sering timbul (pengangguran, inflasi, dan menciptakan pertumbuhan ekonomi yang memuaskan), menjamin agar faktor-faktor produksi digunakan dan dialokasikan ke berbagai kegiatan ekonomi secara efisien, dana memperbaiki keadaan distribusi pendapatan yang tidak seimbang yang selalu terjadi di masyarakat, terutama yang kegiatan ekonominya diatur oleh pasar bebas. (Sukirno, 2010). Dari kedua

8 World Bank, "Meluasnya Ketimpangan di Indonesia", diakses dari http://www.worldbank.org/in/news/feature/2 015/12/08/indonesia-rising-divide pada tanggal 1 Agustus 2017 pukul 19.00 WIB. instrumen kebijakan tersebut, instrumen kebijakan fiskal merupakan instrumen yang paling mungkin untuk melakukan distribusi pendapatan.

Selain dalam bidang ekonomi, pemerintah juga berperan dalam menjaga lingkungan dari dampak buruk adanya pariwisata. Dengan mengintegrasikan antara pembangunan ekonomi wilayah dan lingkungan hidup, perlu dibuat kebijakan ecotourism. Ecotourism merupakan bagian dari pembangunan pariwisata berkelanjutan untuk memenuhi kebutuhan wisatawan dan wilayah tuan rumah sekaligus melindungi dan meningkatkan peluang untuk masa depan. Kebijakan ini mengarah pada pengelolaan semua sumber daya sehingga kebutuhan ekonomi, sosial dan estetika dapat dipenuhi dengan tetap menjaga integritas budaya, proses ekologis yang penting, dan keanekaragaman hayati dan sistem pendukung kehidupan (Anwar, 2012) ${ }^{9}$. Ecotourism diharapkan mampu mengurangi dampak negatif pariwisata serta membangun kesadaran dan penghargaan atas lingkungan sekaligus menawarkan pengalaman-pengalaman yang baru, memberikan keuntungan secara finansial dan meningkatkan kepekaan terhadap situasi sosial \& lingkungan.

\section{METODOLOGI PENELITIAN}

\subsection{Data}

Penelitian ini menggunakan data panel untuk 9 kabupaten/kota yang ada di Provinsi Bali yaitu Kabupaten Jembrana, Kabupaten Tabanan, Kabupaten Badung, Kabupaten Gianyar, Kabupaten Klungkung, Kabupaten Bangli, Kabupaten Karangasem, Kabupaten Buleleng dan Kota Denpasar, dengan periode waktu tahun 20062015. Pemilihan periode ini didasari pada mulai bangkitnya pariwisata pasca kejadian bom Bali yang mengakibatkan perlambatan pertumbuhan seluruh sektor-sektor terkait pariwisata (BPS Provinsi Bali, 2016a ${ }^{10}$, 2016b ${ }^{11}$; Mudrikah, 2014).

Menurut Baltagi (2005) ${ }^{12}$, data panel mampu mengontrol heterogenitas individual serta

9 Jahid MD Anwar, Poverty alleviation through sustainable tourism: A critical analysis of propoor tourism and implications for sustainability in Bangladesh. Research Report, 2012.

10 BPS Bali, Indikator Kesejahteraan Rakyat Provinsi Bali 2015 (Denpasar: BPS Provinsi Bali, 2016). Hal.7.

11 BPS Bali, Tinjauan Perekonomian Bali 2015 (Denpasar: BPS Provinsi Bali, 2016). Hal.108.

12 Badi H. Baltagi, Econometric Analysis of Panel Data (England: John Wiley \& Sons Ltd, Ed., 2005). Hal.4. 
memberikan lebih banyak informasi, variabilitas, derajat kebebasan (degree of freedom), efisiensi, dan mengurangi kolinieritas antar variabel. Data panel juga mampu mengidentifikasi dan mengukur dampak yang tidak terdeteksi dalam data time series dan data cross section murni dan memungkinkan untuk membangun dan menguji model perilaku secara lebih lengkap daripada data time series dan data cross section murni.

Data diperoleh melalui publikasi Badan Pusat Statistik, Dinas Pendapatan Daerah, Dinas Pariwisata, Direktorat Jenderal Perimbangan Keuangan, serta sumber-sumber lain yang dianggap relevan. Adapun variable-variabel dalam penelitian ini didefinisikan sebagai berikut:

a. Pariwisata (DRBSHARE): persentase PDRB sektor pariwisata (perdagangan, akomodasi dan restoran) terhadap total PDRB;

b. Pengeluaran pemerintah (GOV_EXP): pengeluaran pemerintah daerah berdasarkan fungsi pariwisata;

c. Pertumbuhan Ekonomi (GROWTH): laju pertumbuhan PDRB;

d. Ketimpangan distribusi pendapatan (GINI): Gini Ratio.

\subsection{Model}

Penelitian ini bertujuan untuk mengetahui pengaruh sektor pariwisata terhadap ketimpangan distribusi pendapatan. Model yang akan diestimasi dalam penelitian ini adalah sebagai berikut:

GINI $=\beta_{0}+\beta_{1}$ PDRBSHARE $_{i t}+\beta_{2}$ GOV $_{-}$EXP $_{i t}+$ $\beta_{3}$ GROWTHit $+\varepsilon_{i t}$

Untuk menghindari permasalahan dalam pengolahan data dikarenakan gap yang besar antara variabel independen dengan variabel dependennya, persamaan model tersebut ditransformasikan ke dalam bentuk logaritma natural. Bentuk logaritma natural digunakan karena pada umumnya nilai variabel sangat besar dan satuan variabel satu dengan lainnya berbeda. Transformasi logaritma akan membuat hubungan yang tidak linier dalam suatu model dapat digunakan dalam model linier. Selain itu, Transformasi logaritma dapat mengubah data yang pada tidak terdistribusi normal menjadi terdistribusi normal ${ }^{13}$. Berdasarkan hal tersebut, persamaan model penelitian menjadi:

$L N G I N I=\beta_{0}+\beta_{1} L N P D R B S H A R E_{i t}+\beta_{2} L N G O V_{-} E X P_{i t}+$ $\beta_{3} L N G R O W T H_{i t}+\varepsilon_{i t}$

Menurut Wooldridge (1960) ada beberapa pendekatan yang biasa digunakan untuk

13 Gujarati, Essentials of Econometrics, Terj, Julius A Mulyadi (New York: McGraw-Hill Inc., 2006). Hal. 213 mengestimasi model regresi dengan data panel yakni pendekatan Common Effect, Fixed Effect dan Random Effect. Pemilihan teknik estimasi dari ketiga model di atas dapat ditentukan dengan melakukan Uji Chow untuk membandingkan model common effect dengan fixed effect dan Hausman Test untuk menentukan model yang terbaik untuk digunakan dengan membandingkan model fixed effect dengan random effect. ${ }^{14}$

Analisis regresi ini bertujuan untuk mengetahui secara parsial maupun simultan pengaruh variabel independen terhadap variabel dependen serta untuk mengetahui proporsi variabel independen dalam menjelaskan perubahan variabel dependen. Pengujian tersebut meliputi sebagai berikut Uji t (Signifikansi Parsial), Uji-F (Overall Significance Test) dan Uji Koefisien Determinasi $\left(\mathrm{R}^{2}\right)$.

\section{HASIL PENELITIAN}

Peran pariwisata dalam meningkatkan pertumbuhan ekonomi sudah tidak diragukan. Selama beberapa dekade terakhir, pariwisata menjadi salah satu kekuatan utama pertumbuhan ekonomi di banyak negara berkembang dan maju. ${ }^{15}$ Namun demikian, belum banyak penelitian di Indonesia yang menguji pengaruh pariwisata terhadap ketimpangan pendapatan.

\subsection{Pengujian Statistik}

Penggunaan data panel dalam estimasi membutuhkan uji spesifikasi untuk menentukan salah satu model yang sesuai, apakah menggunakan common effect, fixed effect atau random effects. Uji Chow (Chow Test) dilakukan untuk menguji apakah lebih baik menggunakan common effect atau fixed effects. Sedangkan Uji Hausman untuk menguji apakah lebih baik menggunakan fixed effect atau random effects.

Tabel 1. Hasil Chow Test

Redundant Fixed Effects Tests

Test cross-section fixed effects

\begin{tabular}{llll}
\hline \hline Effects Test & Statistic & d.f. & Prob.
\end{tabular}

14 Menurut beberapa ahli ekonometri, jika data panel yang dimiliki mempunyai jumlah waktu (t) > individu (i), maka disarankan menggunakan metode Fixed Effect. Jika sebaliknya, maka disarankan menggunakan metode Random Effect.

15 Menurut Alam \& Paramati (2016) sebagian besar studi mengasumsikan ekonomi yang relatif statis dan fungsional dimana pertumbuhan ekonomi merupakan prioritas tertinggi, dan bukan sistem sosio-ekonomi yang dinamis. 


\begin{tabular}{lrrr}
\hline \hline Cross-section F & 7.327482 & $(8,78)$ & 0.0000 \\
Cross-section Chi-square & 50.444412 & 8 & 0.0000 \\
\hline \hline
\end{tabular}

Sumber: Olah data menggunakan E-views 9

Tabel 2. Hasil Hausman Test Correlated Random Effects - Hausman Test Test cross-section random effects

\begin{tabular}{llcc}
\hline \hline Test Summary & $\begin{array}{l}\text { Chi-Sq. } \\
\text { Statistic }\end{array}$ & Chi-Sq. d.f. & Prob. \\
\hline \hline Cross-section random & 45.921698 & 3 & 0.0000 \\
\hline \hline
\end{tabular}

Sumber: Olah data menggunakan E-views 9

Berdasarkan hasil Chow test pada tabel 1, nilai probabilitas Cross-section F model lebih kecil dari $\alpha$ $(0,0000<0,05)$, artinya model yang paling tepat untuk digunakan adalah Fixed Effect Model (FEM). Pengujian kedua yaitu Haussman Test untuk menguji manakah yang lebih tepat menggunakan model fixed effect atau random effect. Dari hasil diatas, dapat dilihat bahwa model persamaan mempunyai nilai probabilitas cross section random sebesar 0.0000 lebih kecil dari $\alpha$ yaitu sebesar 0.05 , sehingga kesimpulannya model yang akan digunakan dalam penelitian ini adalah model fixed effect.

Tabel 3. Hasil Regresi Panel

Dependent Variable: LNGINI

\begin{tabular}{|c|c|c|c|}
\hline Variable & Coefficient & Std. Error & t-Statistic Prob. \\
\hline LNPDRBSHARE & 1.328576 & 0.352461 & 3.7694300 .0003 \\
\hline LNGROWTH & 0.819326 & 0.168543 & 4.8612310 .0000 \\
\hline$L N G O V$ & 0.063974 & 0.029638 & 2.1585340 .0340 \\
\hline $\mathrm{C}$ & -8.546488 & 1.051198 & -8.1302370 .0000 \\
\hline \multicolumn{3}{|c|}{$R$-squared $\quad 0.656149$} & \\
\hline $\begin{array}{l}\text { Adjusted R-squared } \\
\text { F-statistic }\end{array}$ & \multicolumn{2}{|c|}{0.607658} & \\
\hline$F$-statistic & \multicolumn{2}{|c|}{13.53115} & \\
\hline $\operatorname{Prob}(F$-statistic $)$ & 0.000 & & \\
\hline
\end{tabular}

Sumber: Olah data menggunakan $E$-views 9

Secara matematis output di atas dapat ditulis dalam bentuk persamaan:

lngini $=-8.546488+1.328576$ Inpdrbshare + 0.063974 lngov +0.819326 lngrowth

Secara parsial berdasar hasil pengujian terhadap nilai t-statistik diperoleh Inpdrbshare dan In growth menunjukkan signifikansi pada $\alpha 1 \%$ sedangkan lngov pada $\alpha 5 \%$ (t-tabel $\alpha 1 \%=2.36998$ dan $\alpha 5 \%=1.66256)$. Signifikansi juga bisa dilihat dari Probabilitas masing-masing variabel yang di bawah 0.05 .

Secara simultan (Uji F) menunjukkan bahwa secara bersama-sama, masing-masing variabel bebas mampu memberikan pengaruh yang signifikan terhadap ketimpangan distribusi pendapatan. Hal ini dapat dilihat dari nilai $\mathrm{F}$ statistik sebesar 13.53115 dan T-tabel sebesar 3.10, selain itu juga dapat dilihat dari Prob (Fstatistic) sebesar 0.0000 dimana nilai tersebut lebih kecil dari $\alpha=5 \%$. Uji Koefisien Determinasi (R2) nilai R2 dari hasil regresi ini adalah sebesar 0.6561 yang berarti bahwa variabel independennya (pdrbshare, growth, dan gov) dapat menjelaskan faktor ketimpangan distribusi pendapatan (Gini) sebesar 65,61\%, sedangkan sisanya sebesar 34,39\% dijelaskan oleh faktorfaktor lain yang tidak ada di dalam model.

\subsection{Pariwisata, Pengeluaran Pemerintah, dan Ketimpangan Distribusi Pendapatan}

Pembangunan ekonomi tidaklah semata-mata diukur berdasarkan pertumbuhan PDRB secara keseluruhan, tetapi harus memperhatikan sejauh mana distribusi pendapatan telah menyebar ke lapisan masyarakat serta siapa yang telah menikmati hasilnya. Hubungan yang positif dan signifikan antara pariwisata (PDRB share dan Jumlah wisatawan) mengindikasikan bahwa perkembangan pariwisata di Bali justru menyebabkan ketimpangan distribusi pendapatan. Hasil penelitian ini menguatkan penelitianpenelitian sebelumnya oleh Alam \& Paramati (2016), Incera \& Melchor Fernandez (2015), Marcouiller \& Xia (2008), serta Wattanakuljarus \& Coxhead (2008) yang menyimpulkan bahwa pariwisata di satu sisi akan meningkatkan pendapatan pada rumah tangga, namun di lain sisi pariwisata akan meningkatkan ketidakmerataan distribusi pendapatan.

Peningkatan ketidakmerataan distribusi pendapatan ini dikarenakan pada rumah tangga dengan pendapatan yang tinggi, benefit yang diperoleh lebih tinggi dibandingkan pada rumah tangga dengan tingkat pendapatan yang rendah. Para pekerja mendapatkan upah yang relatif lebih rendah jika dibandingkan dengan keuntungan yang diperoleh para pemilik modal. Pekerja kelas rendah akan mendapat upah sesuai dengan upah minimum yang ditentukan oleh pemerintah. Banyaknya peminat pekerjaan di sektor pariwisata menyebabkan daya tawar pekerja menjadi rendah. Ketimpangan pendapatan di Thailand dikarenakan kebijakan pariwisata bukan mengarah kepada padat karya (Wattanakuljarus \& Coxhead, 2008) ${ }^{16}$, sedangkan di Bali ketimpangan lebih disebabkan pada upah yang rendah.

16 Wattanakuljarus, A., \& Coxhead, I. (2008). Is Tourism-Based Development Good for The Poor? A General Equilibrium Analysis for Thailand. Journal of Policy Modeling, Hal.952. 
Pariwisata di Bali merupakan industri dengan upah rendah dan cenderung menyerap tenaga kerja tidak terampil dan semi-terampil. Walaupun memperoleh upah yang rendah, para buruh di sektor pariwisata tetap bertahan karena kesempatan kerja yang lebih besar dibandingkan dengan sektor lain. Jika dibandingkan dengan sumbangsih penerimaan sektor pariwisata terhadap PDRB di Bali, ini tentu sangat timpang. Terlihat dari Upah Minimun Kabupaten/Kota yang diterapkan di Bali.

Tabel 4. Upah Minimum Kabupaten/Kota Provinsi Bali

\begin{tabular}{|l|c|c|}
\hline Kab/ Kota & \multicolumn{1}{|c|}{2015} & 2016 \\
\hline Badung & $1,905,000$ & $2,124,075$ \\
\hline Denpasar & $1,800,000$ & $2,007,000$ \\
\hline Gianyar & $1,707,750$ & $1,904,141$ \\
\hline Karangasem & $1,700,000$ & $1,895,500$ \\
\hline Bangli & $1,622,000$ & $1,808,530$ \\
\hline Tabanan & $1,706,700$ & $1,902,970$ \\
\hline Klungkung & $1,650,000$ & $1,839,750$ \\
\hline Buleleng & $1,650,000$ & $1,839,750$ \\
\hline Jembrana & $1,622,500$ & - \\
\hline
\end{tabular}

Sumber: www.baliprov.go.id

Dapat dilihat dari Upah Minimum Kabupaten/Kota (UMK) di Provinsi Bali yang tidak terlalu tinggi jika dibandingkan dengan UMK di kota-kota besar lainnya di Jawa Timur maupun Jawa Barat. Tahun 2015 di Jawa Timur besaran UMK adalah Rp2,7 juta untuk wilayah Surabaya, Gresik, Sidoarjo, dan Pasuruan. Kabupaten Badung yang merupakan salah satu Kabupaten dengan PDRB tinggi di Indonesia hanya memberikan UMK sebesar Rp2,1 juta, terhitung kecil jika dibandingkan dengan biaya hidup yang cukup besar di Bali. Hal ini sangat pincang jika dibandingkan dengan penerimaan yang dihasilkan dari sektor pariwisata. Benefit yang diperoleh lebih bisa dirasakan oleh kelas elit dalam masyarakat, seperti pemilik penyedia layanan pariwisata, pengusaha, investor, dan manajer dari perusahaan pariwisata (Alam \& Paramati, 2016). Dilemanya adalah penetapan UMK yang tinggi tentunya akan menguntungkan bagi golongan pekerja, tetapi tidak sebaliknya bagi pengusaha. Penetapan UMK yang terlalu tinggi tentunya akan menambah beban perusahaan dan membuat perusahaan mengurangi tenaga kerja demi efisiensi.

Ketimpangan yang tinggi juga disebabkan adanya perbedaan tingkat upah yang tinggi antar pekerja di sektor pariwisata. Pekerja hiburan di sektor pariwisata misalnya, memperoleh pendapatan yang lebih tinggi jika dibandingkan dengan pekerja dengan skill rendah di sektor pariwisata lainnya (S. Lee, 2011) ${ }^{17}$. Penelitian Apriliani \& Bendesa (n.d.) juga menyebutkan bahwa ada ketimpangan upah yang nyata antar pekerja di sektor pariwisata itu sendiri. Peningkatan sektor pariwisata memang menyebabkan kenaikan pendapatan rumah tangga agregat, namun juga memperburuk distribusi pendapatan. Pengembangan pariwisata justru akan menyebabkan melemahnya sektor pertanian dimana sebagian besar rumah tangga miskin memperoleh penghasilan dari sana (Wattanakuljarus \& Coxhead, 2008) ${ }^{18}$.

Grafik 1. Persentase Tenaga Kerja Sektor Pariwisata dan Pertanian di Bali

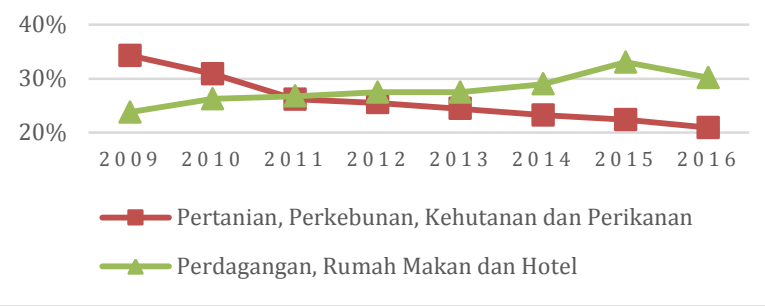

Sumber: BPS Prov. Bali, diolah (2016)

Grafik di atas menunjukkan adanya pergeseran tenaga kerja di sektor pertanian menuju ke sektor pariwisata. Tidak dapat dihindari bahwa akan ada perpindahan tenaga kerja dari sektor non pariwisata ke sektor pariwisata karena melihat peluang kesempatan kerja dan tingkat upah yang lebih baik ${ }^{19}$. Perpindahan pekerja dari sektor non pariwisata ke sektor pariwisata akan memperburuk distribusi pendapatan.

Besarnya penyerapan tenaga kerja sektor pariwisata (lebih dari 30\%) seharusnya bisa menurunkan kesenjangan distribusi pendapatan. Namun kenyataannya, pariwisata belum bisa maksimal dalam mengurangi ketimpangan. Hal ini dikarenakan tingkat upah yang diterima oleh pekerja di sektor pariwisata tidak jauh berbeda jika dibandingkan dengan sektor pertanian karena UMK yang rendah, yang membedakan adalah bekerja di sektor pariwisata telah menjadi kebanggaan dan gengsi yang lebih dibandingkan dengan bekerja di sektor pertanian. Menurut penelitian dari Universitas Udayana tahun 2001, pekerja sektor pariwisata di Bali kurang menonjol

17 Sangkwon Lee. (2011). Income Inequality in Tourism Services- Dependent Counties. Current Issues in Tourism, (November 2014), Hal.42.

18 Wattanakuljarus, A., \& Coxhead, I. (2008). Loc.Cit

19 Perpindahan tenaga kerja antar sektoral tersebut akan berhenti bila tingkat upah yang diharapkan (expected wage) antar sektor tersebut sama (Pratomo \& Saputra, 2011) 
di bidang yang berhubungan dengan kemampuan konseptual, manajerial, dan aspek bisnis lainnya sehingga keunggulan lebih banyak pada front liners atau tingkat pelaksana.

Dengan ketergantungan yang tinggi pada sektor pariwisata, kesenjangan distribusi pendapatan akan semakin melebar untuk daerah dengan sarana pendukung wisata yang tinggi, seperti wilayah Bali Selatan, dengan wilayah yang rendah pendukung wisatanya. Ketimpangan distribusi pendapatan yang tinggi serta peningkatan ketimpangan yang lebih cepat cenderung terjadi pada daerah yang memiliki ketergantungan di sektor jasa pariwisata (S. Lee, 2011). Apabila dikaitkan dengan struktur perekonomian, penyebab kesenjangan ekonomi di Provinsi Bali adalah persebaran titik-titik destinasi pariwisata yang tidak merata. Ketimpangan pembangunan pariwisata di daerah Bali Selatan dengan daerah lainnya (terutama Bali Utara) juga diakibatkan oleh terbatasnya akses serta lamanya waktu tempuh yang diperlukan untuk mengakses objek-objek wisata. Tidak meratanya persebaran ini membuat ketimpangan dalam menikmati manfaat ekonomi dari aktivitas pariwisata. Infrastruktur merupakan salah satu pertimbangan investor dalam menanamkan modalnya. Pemerintah perlu membangun infrastruktur, terutama jalan untuk memperlancar arus wisatawan maupun investasi menuju Bali Utara. Dengan infrastruktur yang memadai, para investor akan tertarik untuk menanamkan modalnya.

Besarnya gap PDRB perkapita tertinggi dan PDRB perkapita terendah antar kabupaten dan kota menunjukkan adanya kesenjangan ekonomi. Ketimpangan yang terjadi merupakan dampak kebijakan program pembangunan jangka panjang daerah Bali yang ditetapkan puluhan tahun yang lalu, yang meletakkan wilayah Bali Selatan sebagai daerah pariwisata. Terjadinya konsentrasi kegiatan ekonomi yang cukup tinggi pada wilayah Bali Selatan jelas akan mempengaruhi ketimpangan pembangunan antar wilayah. Dengan terpusatnya pembangunan pariwisata di Bali Selatan akan mendorong pembangunan ekonominya melalui penyediaan lapangan kerja dan kenaikan tingkat pendapatan masyarakat. Sebaliknya untuk daerah diluar Bali Selatan, dengan rendahnya konsentrasi ekonomi menyebabkan sedikitnya lapangan kerja yang tersedia. Kesenjangan ekonomi antar wilayah ini akan menyebukan terjadinya ketimpangan pada distribusi pendapatan.

Salah satu peran pemerintah dalam menanggulangi kemiskinan adalah melalui kebijakan fiskalnya, salah satunya dengan melalui pengeluaran pemerintah. Pengeluaran pemerintah sektor pariwisata selain untuk meningkatkan pertumbuhan pariwisata, juga diharapkan berperan dalam mengurangi ketimpangan distribusi pendapatan khususnya di sektor pariwisata. Namun penelitian ini memperoleh hasil yang berkebalikan, pengeluaran pemerintah justru meningkatkan ketimpangan. Menurut Danawati, et.al (2016) dan Wahyuni et.al (2014) hubungan positif antara pengeluaran pemerintah dan ketimpangan distribusi pendapatan di Bali disebabkan karena pengeluaran pemerintah belum sepenuhnya terjangkau atau dapat dinikmati oleh masyarakat secara langsung.

Hal ini dapat di logika karena data yang digunakan dalam penelitian ini merupakan pengeluaran pemerintah di bidang pariwisata, bukan pengeluaran pemerintah di bidang pendidikan maupun kesehatan yang dapat mengurangi ketimpangan. Pengeluaran pemerintah di sektor pariwisata lebih ditujukan untuk mendukung kegiatan pariwisata secara umum. Misalnya, meliputi promosi pariwisata, layanan informasi pengunjung, layanan administrasi, dan layanan publik lainnya. Untuk mengurangi kesenjangan pendapatan -dilakukan pemerintah pada berbagai tingkatan- secara langsung berupa pembayaran transfer dan secara tidak langsung melalui penciptaan lapangan kerja, subsidi pendidikan, subsidi kesehatan dan lain sebagainya (Todaro \& Smith, 2012) ${ }^{20}$.

\subsection{Pertumbuhan Ekonomi dan Ketimpangan Distribusi Pendapatan}

Tidak diragukan bahwa pertumbuhan ekonomi di Bali sangat dipengaruhi oleh perkembangan sektor pariwisata. Hasil penelitian ini menunjukkan bahwa pertumbuhan ekonomi yang tinggi di Bali ternyata memberi dampak pada peningkatan ketimpangan distribusi pendapatan. Menurut Kuznets (1955), pertumbuhan ekonomi akan mempengaruhi distribusi pendapatan, upah untuk pekerja yang lebih tinggi tetapi diikuti dengan ketimpangan distribusi pendapatan yang meningkat. Pertumbuhan ekonomi di negara berkembang pada awalnya cenderung menyebabkan tingginya tingkat kemiskinan dan ketidakmerataan distribusi pendapatan. Penelitian ini menemukan hasil bahwa pertumbuhan ekonomi akan berpengaruh pada naiknya ketimpangan distribusi pendapatan.

Penjelasan kenapa pertumbuhan yang tinggi
juga meningkatkan ketimpangan adalah
dikarenakan unequal return pada input produksi
pada pasar tidak sempurna dan persaingan yang
tidak sehat (Krongkaew \& Kakwani, 2003)

20 Todaro \& Smith, "Economic Development (11th ed.)", (Boston, USA: Pearson Education, Inc.,2012) Hal.241-249.

21 Krongkaew, M., \& Kakwani, N. (2003). Loc.Cit 
Kondisi infrastruktur di wilayah Bali Selatan yang lebih memadai dibanding wilayah Bali lainnya membuat para investor lebih senang untuk menanamkan modalnya di daerah Bali Selatan karena dinilai lebih dapat memberikan return yang diinginkan atas investasinya. Kondisi ini membuat pertumbuhan ekonomi Bali sebagian besar masih terpusat di wilayah Bali Selatan, yang mengakibatkan pertumbuhan ekonomi tiap daerah di Bali tidak seimbang. Hal tersebut menyebabkan ketimpangan distribusi pendapatan menjadi masalah yang serius.

Gambar 2. Kondisi Pertumbuhan Dan Ketimpangan Kabupaten Kota di Bali

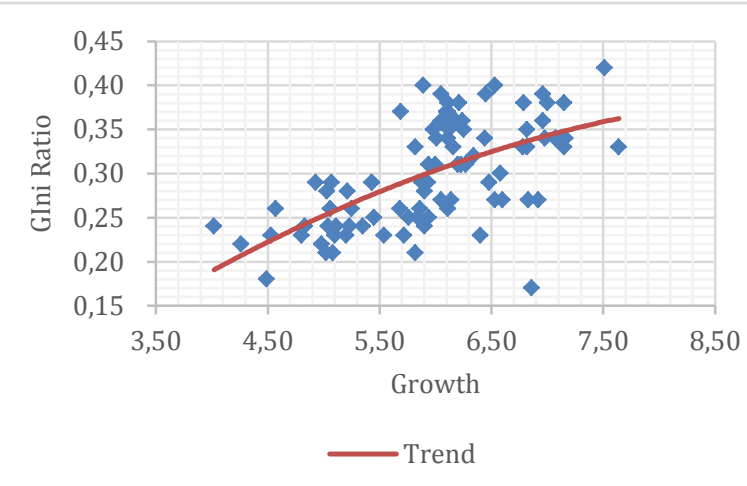

Sumber: BPS (diolah)

Dari kondisi pertumbuhan serta ketimpangan pada Kabupaten/Kota di Bali, terlihat tren positif antara pertumbuhan dan ketimpangan dan ada kecenderungan untuk menurun. Kondisi ini sesuai dengan hipotesis Kuznets (1955) yaitu di awal pembangunan ekonomi kesenjangan pendapatan semakin meningkat sejalan dengan semakin meningkatnya pertumbuhan ekonomi. Dalam jangka pendek terlihat ada korelasi positif antara pertumbuhan pendapatan perkapita dengan kesenjangan pendapatan. Artinya, dalam jangka pendek meningkatnya pendapatan akan diikuti dengan meningkatnya kesenjangan pendapatan. Namun dilihat dari trend diatas, dalam jangka panjang hubungan keduanya menjadi korelasi yang negatif yang artinya peningkatan pendapatan akan diikuti dengan penurunan kesenjangan pendapatan. Hubungan yang positif antara pertumbuhan ekonomi Bali dan ketimpangan juga disebabkan pertumbuhan ekonomi Bali yang basisnya kurang kuat. Ini tercermin dari struktur pembentuk pertumbuhan ekonomi yang mayoritas berasal dari konsumsi, bukan dari investasi. Secara mikro, kredit perbankan juga didominasi oleh kredit konsumsi.

Kuznets juga menekankan adanya perubahan struktural dalam pembangunan ekonomi, dimana dalam prosesnya terjadi pergeseran dari sektor tradisional ke sektor modern serta berkembangnya sektor industri dan jasa. Adanya pergeseran tersebut menyebabkan produktivitas dan upah tenaga kerja di sektor modern menjadi lebih tinggi jika dibandingkan dengan sektor tradisional. Perbedaan tingkat upah tersebut -yang mengakibatkan naiknya pendapatan perkapita masyarakat- mengakibatkan peningkatan ketidakmerataan distribusi pendapatan antar kedua sektor tersebut.

\section{Grafik 2. Struktur Ekonomi Provinsi Bali}

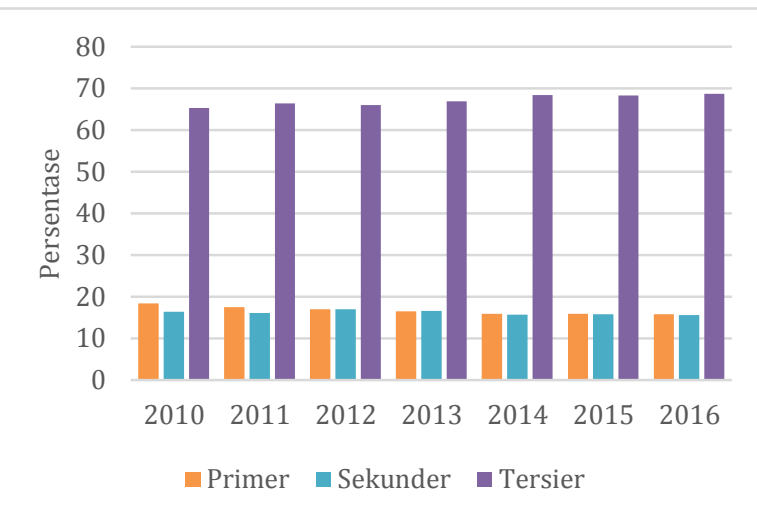

Sumber: BPS (diolah)

Dilihat dari struktur ekonomi Provinsi Bali, saat ini Bali sangat menggantungkan perekonomiannya pada industri tersier. Terlihat jelas kontribusi lapangan usaha tersier mendominasi perekonomian Bali dengan kontribusi yang terus meningkat. Sementara itu kontribusi lapangan usaha primer terus menurun kontribusinya. Penurunan kontribusi sektor primer terutama pertanian akan meningkatkan kesenjangan distribusi pendapatan, karena rumah tangga miskin mayoritas menggantungkan pendapatannya pada sektor primer.

\section{KESIMPULAN DAN SARAN}

Penelitian ini dipicu oleh pro-kontra mengenai dampak pariwisata terhadap ketimpangan distribusi pendapatan, walaupun di lain sisi para peneliti sepakat bahwa industri pariwisata akan berdampak pada peningkatan pendapatan agregat rumah tangga. Pro-kontra juga terjadi mengenai pengaruh pertumbuhan ekonomi terhadap ketimpangan distribusi pendapatan.

Pariwisata dan pengeluaran pemerintah serta pertumbuhan ekonomi di Bali menyebabkan naiknya ketimpangan distribusi pendapatan. Pariwisata menyebabkan ketimpangan dikarenakan benefit yang diperoleh antara pemilik modal dan pekerja kelas atas yang lebih tinggi jika dibandingkan pekerja kelas bawah. UMK yang masih rendah kurang bisa menaikkan taraf hidup masyarakat. Persebaran titik-titik destinasi pariwisata yang tidak merata juga menyebabkan ketimpangan masyarakat dalam menikmati manfaat ekonomi dari aktivitas pariwisata. 
Pengeluaran pemerintah di sektor pariwisata lebih ditujukan untuk mendukung kegiatan pariwisata secara umum. Perekonomian yang tumbuh tinggi di Bali lebih bersandar pada konsumsi masyarakat sebagai pembentuknya, bukan pada investasi. Hal ini menyebabkan pertumbuhan ekonomi belum mampu meningkatkan kesejahteraan masyarakat. Pertumbuhan yang tinggi justru menyebabkan ketimpangan distribusi pendapatan masyarakat, namun dilihat dari tren nya dalam jangka panjang ketimpangan akan turun. Penelitian ini menunjukkan bahwa hipotesis Kuznets terbukti di Bali.

Langkah untuk meratakan distribusi pendapatan, terutama di sektor pariwisata, dapat dilakukan dengan kebijakan mengenai upah minimum sektoral. Upah minimum sektoral akan mengurangi dampak dari ketimpangan pendapatan serta perpindahan pekerja antar sektoral. Pemerataan investasi terutama pada wilayah di luar Bali Selatan perlu dilakukan agar pariwisata dapat dinikmati oleh masyarakat Bali pada umumnya.

\section{IMPLIKASI DAN KETERBATASAN}

Hasil penelitian ini menunjukkan bahwa pariwisata yang seharusnya mampu mengurangi ketimpangan distribusi pendapatan, karena multiplier effect yang besar, belum mampu meningkatkan kesejahteraan masyarakat secara luas. Pengembangan pariwisata di Bali seharusnya bukan hanya terfokus pada peningkatan jumlah wisatawan dan penerimaan untuk APBD saja, namun juga ke arah pro poor tourism. Pengembangan pariwisata harus dihubungkan dengan sektor pertanian, karena di sektor inilah penduduk miskin banyak menggantungkan hidupnya.

Keterbatasan penelitian ini adalah dalam hal menjelaskan pertumbuhan ekonomi dan ketimpangannya. Idealnya menggunakan data secara time series agar mampu menjelaskan perubahan ketimpangan dan pertumbuhan akibat perubahan dari waktu ke waktu. Penelitian ini juga hanya menggunakan variabel share PDRB dan pengeluaran pemerintah di sektor pariwisata untuk mewakili pariwisata secara keseluruhan. Penelitian selanjutnya dapat menambah variabel yang lebih kompleks (misalnya: jumlah hotel, restoran, wisatawan, tenaga kerja, dll) untuk dapat melihat hubungan yang lebih jelas antara pariwisata dan ketimpangan. Penggunaan variabel pengeluaran pemerintah dengan menggunakan fungsi pariwisata lebih ditujukan pada peran pariwisatanya, bukan fungsi pemerintah secara umum sehingga belum mampu menunjukkan peran pemerintah untuk mengatasi ketimpangan.

\section{DAFTAR PUSTAKA (REFERENCES)}

Alam, M. S., \& Paramati, S. R. (2016). The impact of tourism on income inequality in developing economies: Does Kuznets curve hypothesis exist? Annals of Tourism Research, 61, 111126.

https://doi.org/10.1016/j.annals.2016.09.0 08

Anwar, J. M. (2012). Poverty alleviation through sustainable tourism: A critical analysis of propoor tourism and implications for sustainability in Bangladesh. Research Report Presented to Professor COOPER Malcolm J. M. In Partial Fulfillment of the Requirements for the Degree of Master of Science in International Cooperation Policy.

Ashley, C., Roe, D., \& Goodwin, H. (2001). Pro-Poor Tourism Strategies: Making Tourism Work For The Poor. Pro-Poor Tourism Report. Retrieved from http://www.odi.org/sites/odi.org.uk/files/o di-assets/publications-opinionfiles/3246.pdf

Baltagi, B. H. (2005). Econometric Analysis of Panel Data. (JohnWiley \& Sons Ltd, Ed.) (3th ed.). England.

BPS Provinsi Bali. (2016a). Perkembangan Indikator Regional Provinsi Bali 2015. Denpasar: BPS Provinsi Bali.

BPS Provinsi Bali. (2016b). Tinjauan Perekonomian Bali 2015.2 Denpasar. https://doi.org/10.1002/ccr3.505.PMID

Danawati, S., Bendesa, I. K. G., \& Utama, M. S. (2016). Pengaruh Pengeluaran Pemerintah Dan Investasi Terhadap Kesempatan Kerja, Pertumbuhan Ekonomi Serta Ketimpangan Pendapatan Kabupaten/Kota Di Provinsi Bali. E-Jurnal Ekonomi Dan Bisnis Universitas Udayana, 7, 2123-2160.

Gatti, P. (2013). Tourism, welfare and income distribution: The case of Croatia. Original Scientific Paper, 61(1), 53-71.

Incera, A. C., \& Melchor Fernandez. (2015). Tourism and income distribution: Evidence from a developed regional economy. Tourism Management 48, 48. https://doi.org/10.1016/j.tourman.2014.10. 016

Krongkaew, M., \& Kakwani, N. (2003). The Growth - equity trade-off in Modern Economic Development : the case of Thailand. Journal of Asian Economics, 14(January), 735-757. https://doi.org/10.1016/j.asieco.2003.10.0 03 
Kuznets, S. (1955). Economic Growth and Income Inequality. The American Economic Review, 45(1), 1-28.

Lee, C., \& Kang, S. (1998). Measuring earnings inequality and median earnings in the tourism industry. Tourism Managementism Management, 19(4), 341-348.

Lee, S. (2011). Income inequality in tourism services- dependent counties. Current Issues in Tourism, (November 2014), 37-41. https://doi.org/10.1080/13683500802248 001

Li, H., Jason-Li Chen, Li, G., \& Goh, C. (2016). Annals of Tourism Research Tourism and regional income inequality: Evidence from China. ANNALS OF TOURISM RESEARCH, 58, 81-99. https://doi.org/10.1016/j.annals.2016.02.0 01

Li, H., \& Zou, H. (1998). Income Inequality is not Harmful for Growth: Theory and Evidence, 2(3), 318-334.

Marcouiller, D. W., \& Xia, X. (2008). Distribution of income from tourism-sensitive employment. Tourism Economics, 14(November 2005), 545-565.

Mudrikah, A. (2014). Kontribusi Sektor Pariwisata Terhadap Gdp Indonesia Tahun 2004-2009. Economics Development Analysis Journal, 3(2), 362-371. Retrieved from http://journal.unnes.ac.id/sju/index.php/ed aj/article/view/3844

Pratomo, D. S., \& Saputra, P. M. A. (2011). Kebijakan Upah Minimum Untuk Perekonomian Yang Berkeadilan : Tinjauan UUD 1945. Journal of Indonesian Applied Economics, 5(2 Oktober 2011), 269-284.

Todaro, M., \& Smith, S. (2009). Ekonomi Pembangunan (1st ed.). Jakarta: Bima Grafika.

Todaro, M., \& Smith, S. (2012). Economic Development (11th ed.). Boston, USA: Pearson Education, Inc.

Wahyuni, I. G. A. P., Sukarsa, M., \& Yuliarmi, N. (2014). Pengaruh Pengeluaran Pemerintah Dan Investasi Terhadap Pertumbuhan Ekonomi Dan Kesenjangan Pendapatan Kabupaten/Kota Di Provinsi Bali. Jurnal Ekonomi Dan Bisnis Universitas Udayana, 8, 458-477.

Wattanakuljarus, A., \& Coxhead, I. (2008). Is tourism-based development good for the poor? A general equilibrium analysis for Thailand. Journal of Policy Modeling, 30, 929-955. https://doi.org/10.1016/j.jpolmod.2008.02. 006

Wooldridge, J. M. (1960). Econometric Analysis of cross section and panel data. London: The MIT Press.

Yoeti, 0. A. (2008). Perencanaan dan Pengembangan Pariwisata. Jakarta: Pradnya Paramita. 